This is the Accepted Version of an article which will be published by Brill in Middle East Law and Governance: http://www.brill.com/middle-east-law-and-governance

Accepted Version downloaded from SOAS Research Online: http://eprints.soas.ac.uk/22221/

\title{
Art, power and knowledge: claiming public space in Tunisia ${ }^{1}$
}

$$
\text { C. Tripp }
$$

\section{Introduction}

Tunisia's recent political history has demonstrated the centrality and urgency of battles for public space in shaping the future of the republic. The public spaces of Tunisian towns and cities were key battlegrounds in the revolution that overthrew President Ben Ali in 2011, helping to produce, direct and amplify the force of resistance. It was here that the power of the people became manifest and here that the role of visible, shared performances was central. Through the use of their bodies, amplified through visual and artistic interventions, members of the public asserted themselves and their right to be taken seriously. On the streets of cities across Tunisia graffiti, street art, performances, demonstrations, banners and slogans captured the nature of the struggle and provoked debate among members of the public who were beginning to find their many voices. Artists as activists were often part of the struggle itself, bringing a critical intelligence to bear on power, contributing to unsettling and then unseating the regime. This resonated with millions across the country, encouraging the expression of ideas that confronted the dictatorship of Ben Ali at a particular moment in time with expulsion from the very spaces that he and his clan had hitherto monopolised. 'Dégage/Irhal' was more than a slogan; it was the enunciation of a political principle of exclusion from the new republic.

Nor was this simply the case in what could be called the 'heroic' period of the Tunisian revolution. Tunisian politics since 2011 has shown that public spaces remain central to emerging political debate. An activist public has created and has often had to defend public space, assisted and encouraged by citizen artists amongst others, generating debates and giving substance to competing, and sometimes deeply opposed political visions. For this very reason, artistic interventions have had the power to provoke and are often intended to do so. As the past few years have shown, there are those within the state machinery and those in society at large who have objected, sometimes violently, to the specific images, words and lyrics used by creative artists, as well as to forms of artistic expression in dance and song. Artists' ability to present versions of the truth that seem to contradict long held and scarcely questioned beliefs, both secular and religious, has been as unsettling in Tunisia as it has been elsewhere throughout history.

1 The author wishes to acknowledge the support of a British Academy-Leverhulme Small Research Grant in carrying out the research for this paper. The author also acknowledges with gratitude the assistance in Tunis of Mohamed Ashraf Ayadi of the Tunisian Institute for Human Rights Studies. 
Tunisian experience has repeatedly given substance to the contention that public space is a location that is both constitutive of and constituted by activist citizens, a site for the assertion of their claims, their rights and their identities. The public spaces of Tunisia, both figurative and literal, have allowed those claims and rights to become knowable features of the political landscape, to be taken into account by established power, and also by their fellow citizens in the calculation of political possibilities. Public space is therefore intertwined with notions of contestation, either to preserve the space from encroachments of state and other authorities, or to provide the arena in which advocates of contending ideas face up to each other. ${ }^{2}$ This has been amply borne out by the course of Tunisian politics since the establishment of the Second Republic, where direct action, occupation, demonstration and confrontations in public space have been a running accompaniment to the institutionalised forms of contention of competitive elections, parliamentary debates and the organisations that monitor state institutions. The events of spring 2011, but also of the summer of 2013, showed the importance of public space in defending and asserting the rights and claims of the public in the face of power, and in holding power accountable. ${ }^{3}$

It is in this regard that art - visual, plastic art, but also performance, dance and song - have played important roles. Artistic interventions in public space highlight issues for debate, but are also capable of engaging and mobilising people around such issues, touching their imaginations and helping them to see other facets of power and of themselves. In this sense, artistic interventions can challenge or throw into doubt the dominant rules of what can and cannot be seen, providing the resources to make possible new forms of knowledge, of the self, of historical narrative and of social mores. For that very reason it can unsettle and even enrage those who may have taken these things for granted. At the same time, artists, like other citizens, are not operating in a vacuum, driven simply by an impulse derived from the nature of creative autonomy. As citizens, they too have their own agendas, visions for the future of Tunisia and fears about the direction in which it may be heading. As artists, however, they have the capacity to make these concerns visible, projecting a set of ideas, fears and ambitions into public space. This is part of the power of art and is central to its mode of public contestation, visible in Tunisia as the circumstances of revolutionary possibility make concrete opposing visions of the country's future.

The artists and artistic interventions that will be examined in this article are precisely those that have provoked such debates and sometimes counterreactions, intentionally, but also as an outcome of their modes of expression. Those they have addressed, but also provoked, have ranged from holders of

2 Neil Smith and Setha Low 'Introduction: the imperative of public space', in S. Low and N. Smith (eds.) The Politics of Public Space (London: Routledge, 2006) pp. 3-16

3 Kaveh Ehsani ‘Radical Democratic Politics and Public Space', International Journal of Middle Eastern Studies 46 (2014) pp. 159-161 
public office, through agents of the unreconstructed state security services to fellow citizens, outraged in some cases by a message and a medium that challenge their own preconceptions. Studying some of these confrontations shows the larger issues are at stake. In Tunisia, as elsewhere, it is not simply that artistic freedom is a barometer of a free society. More centrally, the artist, as someone who brings a creative moral intellect to bear on things that may be taken for granted, can open up new ways of seeing the world, provoking debates about the fundamental rights that underpin not simply freedom of expression, but also the access to public goods that make such freedoms meaningful.

In the Tunisian case such interventions have consequently initiated debates amongst some artists, aware of the ambiguities of art and of art production itself in a country where significant social and economic inequalities are so entrenched. In seeking to address and to inform the public, they have to acknowledge that a lack of familiarity with the forms of artistic expression may be a barrier to comprehension. This is a familiar tension, witnessed in other countries where artists intend public engagement, striving to illuminate disguised forms of inequality, but where their art may itself be the product of privileged access to educational and cultural resources. In Tunisia these concerns have also been present as artists, in their role as citizen-artists, tread the line between the shock of the new and the incomprehension of those whom they are trying to reach. It is this that has motivated some to take practical steps to engage a more diverse public and to provide the resources and training that can open up the transformative potential of art through wider awareness, thereby seeking to deepen the knowledge producing potential of art itself.

\section{Making power relations visible in the revolution}

The Tunisian revolutionary movement that culminated in the overthrow of President Ben Ali was supremely visible. Indeed, its very visibility was part of its strength, from the widely shared image of the blazing figure of Mohamed Bouazizi in December 2010, to the mass demonstrations that filled the streets of Tunisia's towns and cities. It gave the impression of an entire population in revolt. In some respects, it was a classic performance of revolution, carried out by an enraged populace, reclaiming public space in defiance of the government and withstanding the violence used against them. It was reported that the visual impression of an unstoppable tide of popular anger, conveyed by TV stations and social media, contributed decisively to Ben Ali's abrupt departure, neatly turning the logic of his surveillance state against him. ${ }^{4}$ It also had an impact on his international backers. They had nothing more go on than the sight of hundreds of thousands of Tunisians ordering their president to leave and it was on this basis

${ }^{4}$ Abdelaziz Belkhodja \& Tarak Cheikhrouhou 14 janvier - l'Enquête (Tunis: Apollonia editions, 2013) pp. 51-92 
that they too came to the conclusion that it was indeed 'game over', as one of the January 2011 banners in the Avenue Bourguiba in Tunis so memorably put it. ${ }^{5}$

Even if such open forms of protest and defiance cannot be classified as 'art' in the generally accepted meaning of the term, they nevertheless bear a strong resemblance to artistic interventions, linking them to the aesthetics of power in a number of ways. This becomes apparent both in their forms of presentation, but also in their capacity to have an impact through the mobilisation of affect on people's imaginations and moral sensibilities. Rancière's understanding of the 'distribution of the sensible' is no less applicable to these forms of selfpresentation than to other more conventional forms of artistic representation. ${ }^{6}$ To say that Bouazizi's terrible act of self-immolation was or became a powerful aesthetic gesture is not to denigrate or in any way to diminish this act of genuine despair and courage. However, it does remind us of the deliberately spectacular nature of the act, where the staging and the method were consciously constructed. For the subject, the very visibility and effect on others was part of the process. This was even more the case when it came to the calculated reproduction of the image of his burning body by those who saw it as a way of indicting the authorities that had brought him to this point of desperation. The image, therefore, took on a life of its own as an image even while the life of the subject ebbed away.

Art, artifice and artefact had after all long been part of established power in Tunisia, giving highly visible substance to the structural and coercive power of the ruler. Ben Ali's removal of Bourguiba's equestrian statue from the town centre of Tunis was a clear signal of the change of regime - just as the earlier removal of the manifestly colonial statue of Jules Ferry from the same spot soon after independence had been a similar visual signal of a new political order. The proliferation of huge billboard portraits of President Ben Ali throughout Tunisia had been part of what it meant to rule, being both representation in and symbolic domination of public space. With their messages and body language, these were intended to reassure the population that their leader had their best interests at heart. Of course they also served to remind Tunisians that he, or his agents, were watching their every move. Needless to say, the vast images also became an object of scorn for many, with subversive interpretations of their true meaning spreading among Tunisians as a form of quiet resistance. ${ }^{7}$

5 Barrack Obama: “We will long remember the sight of the Tunisian people seeking to make their voices heard" Statement by the President on the events in Tunisia, Office of the Press Secretary, The White House, 14 January 2011 https://www.whitehouse.gov/the-press-office/2011/01/14/statement-presidentevents-tunisia

6 Jacques Rancière The Politics of Aesthetics - the distribution of the sensible (London: Continuum, 2004) (tr. Gabriel Rockhill) pp. 7-19

7 Laryssa Chomiak 'Spectacles of power: locating resistance in Ben Ali's Tunisia', Portal 9 Issue No. 2 The Square, Spring 2013 p. 1 - http:/ / portal9journal.org 
It is this order of the visible that artistic interventions can challenge so successfully. Spectacular attacks on the art works of the dictatorship were part of the repertoire of revolution and involved defacing giant portraits of Ben Ali, the burning and looting RCD buildings, as well as houses of the Trabelsi clan. These were not simple acts of destruction. They had a symbolic and aesthetic resonance as strong as that of the originals, reversing the message of protection/surveillance and showing that something fundamental had shifted in the ordering of power. ${ }^{8}$ It also opened the way for creative and artistic efforts to drive home the message that public space had been reclaimed and that the old order had fallen. Thus, in some places Ben Ali's face on a billboard was replaced by the words ' 404 Not Found' (the notorious message that used to flash up when seeking to access any internet site deemed undesirable by the Ben Ali regime). In another case, as part of the public art project organised by Slim Zeghal, Marco Berrebi and JR 'Artocratie en Tunisie', the former president's face was replaced by that of a huge portrait of an ordinary Tunisian. ${ }^{9}$ As for the gutted and looted Trabelsi houses in Gammarth and elsewhere, they served as canvases for talented graffitists, and not so talented amateurs, to demonstrate their contempt for the old regime and their hope for a new Tunisia. ${ }^{10}$

\section{Challenging the unreconstructed state}

In the aftermath of the fall of Ben Ali those who wished to defend newly appropriated public space and the rights associated with it were concerned that less visible forms of power still controlled the lives of Tunisians, entrenched as they were within the state machinery. In particular, there was enduring mistrust of the security services, especially those of the ministry of interior, largely untouched by the revolution, as well as fear that the cadres of the disbanded RCD were regrouping. There was also concern about the habits of state power that might reassert themselves even amongst those newly elected to public office unless held in check by an activist public. These concerns gave rise to numerous civil society organisations that played effective roles in maintaining the pressure for transparency and visibility as the work of Bawsala, its affiliate al-Marsad, Iwatch and many human rights organisations have testified.

This was also a political task to which many artists contributed, using various media, making the sinews of power visible and often testing the capacity of the

8 Again this is a common enough trope in states of revolution - see Dario Gamboni, The Destruction of Art - iconoclasm and vandalism since the French Revolution (London: Reaktion Books, 1997)

9 JR Artocratie en Tunisie - projet Inside Out de JR (Tunis: Cérès editions, 2011) pp. 38-9

10 Amanda Rogers 'For a leaderless revolution, a monument with no curator: a walk through Imed Trabelsi's looted villa', Mideast Art 12 July 2012 -

http:/ / www.aslanmedia.com/arts-culture/mideast-art/7267-for-a-leaderlessrevolution-a-monument-with-no-curator-a-walk-through-imed-trabelsi-s-looted-villa 
post-revolutionary governments to tolerate unfettered expression. It became the mission of a number of Tunisian artists to forestall efforts to establish new forms of hegemony and conformism by defying existing, sometimes unspoken, rules about what can and cannot be revealed, what may or may not be put up for open and public discussion. Such artists provoked established power to reveal itself and thus contributed to the substantiation of insurgent public space, not merely as a physical presence but as the opening of lines of sight upon the hidden spaces of power. They joined with others in making transparent that which was opaque and in doing so helped to acquaint people with their rights and their potential in ways that also captured their imaginations.

Some of the earliest and in many respects most spectacular manifestations of such mistrust concerning the resilience of the old state order came in the protests and sit-ins of Casbah I and Casbah II in January and February 2011. They defeated attempts by Ben Ali's prime minister, and much of his cabinet, to stay in office. They also forced the dissolution of the RCD, paving the way for the caretaker government that would oversee elections in October 2011. Appropriately enough, it was here that the art collective Ahl al-Kahf ${ }^{11}$ had its origins. Initially it brought together street artists and graffitists who were responsible for art on the walls in and around Casbah Square. They were highly critical of attempts to maintain the old regime, spraying up stencils of Ben Ali on government buildings above the phrase 'those who misled him are still in here'. As they expanded to include media such as music and web design, one of the spokespeople of this deliberately anonymous group made clear their understanding of the relationship between art and politics: 'Politics for us is not based on democracy and parliament, but is the politics of the bios, of life. We consider art as a form of resistance against forms of power and domination....so to make art is to make politics. To make street art is to choose to work in the streets and not the galleries. This in itself is a political choice. $^{12}$

Another art collective that emerged at the same time - ZIT (Zombie Intervention Tunisie) - comprised a number of graffitists and street artists who had been active before the revolution and who had had numerous run-ins with the authorities. For some of them, the revolution provided opportunities to extend their range and the scope of their art, using the slogan 'Murs blancs, peuple muet' [blank walls, speechless people $]^{13}$. For others, it seemed to provide an opportunity to

11 The name Ahl al-Kahf refers to the 'People of the Cave' or the 'Seven Sleepers of Ephesus', depending upon which tradition is being used - a common story across the Near East and Mediterranean worlds about a group of men who fled to a cave to escape a tyrant, fell asleep and then awoke many years later when the world had changed.

12 Nicholas Korody 'The Revolutionary Art: Street Art Before and After the Tunisian Revolution' (2011) Independent Study Project (ISP) Collection, Paper 1134, pp. 32-33 http://digitalcollections.sit.edu/isp_collection/1134

13 Dounia Georgeon film: 'Murs blancs, peuple muet' (2011) - http:/ / latelelibre.fr/libreposts/doc-murs-blancs-peuple-muet/ 
become better known (unlike Ahl al-Kahf, they did not seek anonymity) and indeed to enter into new commercial ventures. This led to differences within the group. Meen-One (Moeen Gharby), for instance, seemed to represent a more obviously political edge, using his art to express his hatred of the police by using the internationally known slogan (in English) 'All Cops Are Bastards' on the walls of Tunis, and stating in December 2011 'that the revolution didn't make a big difference to life...I think it's the same situation - democracy and freedom didn't (and don't) exist and we must continue working to create it - even now the political system is lying' ${ }^{14}$ Others within the group, such as Ismat and Sk One, seemed to have a more individualist approach to artistic expression, even if the sites were still the public spaces of Tunisia's cities, leaving them open to accusations of having given in to temptations such as self-promotion and the commercial patronage of their art. ${ }^{15}$

Visual expressions of artistic freedom in public space were not confined to graffiti and to street art. The challenge was also taken up by performance artists and by dancers, using the streets for their stage and transforming public space at the same time as reclaiming it. In doing so, they were challenging existing ideas about order in public space, puzzling and sometimes enraging the police who held to a more restrictive set of ideas about public order. Some of the performers were also seeking to make visible the cynicism of those entrepreneurs of revolution who were hoping to profit for their own political advancement. This was personified by Moufida Fedhila who dressed as Superman for her performance of the persona 'Super Tunisian' in Avenue Bourguiba in Tunis during the summer of 2011. In a satire on all the politicians and parties that had emerged to promise Tunisians everything they could desire, she set up her stall, calling on Tunisians to vote for her imaginary programme to solve all the country's problems. She was hoping to wake people up to the hollow nature of the promises of those politicians who held out a (non-existent) miraculous solution for all of Tunisia's ills. ${ }^{16}$ Her art was reclaiming public space through bodily enactment. It also alerted Tunisians to the power and ambition lurking behind all the promises in the new world of competitive vote catching, revealing hegemony in the making and thereby trying

14 Korody (2011) p. 27; Dounia Georgeon 'Revolutionary graffiti: street art and revolution in Tunisia', Wasafiri 27/4 (December 2012) p. 75

15 In succumbing to such temptations, these artists have much in common with graffitists in other countries: their work may emerge from political protest, but it is then work in the public sphere and, as such, may become the subject of the commercial logic of such a sphere, given the power of commodification in neoliberal capitalism. It testifies to the ambivalent character of any non-ephemeral artwork as both material creative expression and potential commodity - Luke Dickens 'Pictures on Walls? Producing, pricing and collecting the street art screen print', City 14/1-2 (2010) pp. 63-81; CDH 'Notes on the commodification of street art', Art Monthly Australia 263 (September 2013) pp. $42-44$

16 Rachida Triki ‘Enjeux sociopolitiques des arts contemporains en Tunisie', Archivio Anthropologico Mediterraneo XVI (2013) 15/1 p. 26 
to pre-empt it. The performance certainly touched a raw nerve in the unreconstructed security apparatus since she found herself periodically harassed, both verbally and physically, by plain-clothes police officers. ${ }^{17}$

Performances of defiance, provoked by, but also provocative of the authorities, became more frequent as the coalition government, formed after the elections of October 2011, used the considerable powers at its disposal to maintain an order more to its liking. For activist citizens and the artists among them, this was precisely what they wanted to avoid: the re-establishment of the heavy-handed state in the name of order, providing a clear field of operation for those within the state administration who had always found authoritarian habits congenial. It became their mission to alert Tunisians to the creeping reinstatement of the security apparatus and the authoritarian default position even of democratically elected politicians. Thus, when in April 2012 the government, impatient of the frequent demonstrations outside the ministry of the interior, set up barricades of razor wire on Avenue Bourguiba, people responded en masse, turning up with books, often freely distributed, to line the avenue. The silent protest only succeeded in having the barricades shifted, not removed, but it made a clear statement that the streets belong to the people - and also echoed the famous 2010 'Tunisie en blanc' protest in much the same place, thereby pointedly making the connection between the repression of Ben Ali and the repressive instincts of the new government. ${ }^{18}$

These instincts became even more apparent in 2013 at the funeral of the assassinated politician and leftist lawyer, Chokri Belaid. The police, alarmed by the size of the demonstration at his funeral and by the mood of the demonstrators who blamed the Ennahda dominated coalition government for his death, fired tear gas and used baton charges in scenes reminiscent of Ben Ali's last days in power. A startling and moving film clip circulated of two young Tunisians, Abdelkader Brihli and Emna Mouehli, emerging from the clouds of tear gas and dancing in the street, reclaiming public space from the police, affirming their right to be there and their ability to defy the authorities. It was only a short film clip but, as an expression of defiance and as an assertion of rights, it has a powerful effect. $^{19}$

The performance artists' group Fanni Raghman Anni (my art in spite of myself), led by Seifeddine Jlassi, has also used its art to engage with the public and alert it to human rights abuses by agents of the state and by others. As Jlassi said: 'We

17 Aurélie Machghoul ‘Tunisie: 1'art en espace public, révélateur des enjeux d'une société', Archivio Anthropologico Mediterraneo XVI (2013) 15/1 p. 32; Selima Karoui ‘La place de l'art dans l'espace public tunisien' (1) Nawaat 3 March 2014 https:/ / nawaat.org/portail/2014/03/03la-place-de-lart-dans-lespace-public-tunisien-1/ 18 Rachel Shabi 'The Arab Spring began in Tunisia and now its artists and dancers are keeping the flame of protest alive', Aeon 9 May 2013 - http:/ / aeon.co/magazine/culture 19 Frida Dahmani 'Tunisie: la danse, art du combat', Jeune Afrique 27 February 2013 www.jeuneafrique.com/138214/culture/; Machghoul (2013) p. 33 
wanted to come with new forms of protest, new forms of expression and entertainment even, and perform them in alternative places such as the central market, or simply the streets'. ${ }^{20}$ In January 2015, as part of their campaign against the death penalty (it remains on the statute book in Tunisia but there have been no executions since 1991), the group staged a performance entitled 'Three Points' on Avenue Bourguiba. At the same time as publicising human rights violations through drama, the group also used the opportunity to raise the issue of teenage suicides, a topic given little publicity and attributed by some to the pressures on students at school. The combination of these two issues within the same performance suggests that a connection was being made between the latent violence of the state and the hidden or structural violence of an educational system that drives young people to take their own lives. Although some of the spectators were reportedly puzzled by the performance and not all appreciated the group's characteristic paint throwing, others responded positively. ${ }^{21}$

As performance artists and dancers discovered, the security forces were often more bewildered than enraged by their interventions and for the most part did not act against their appropriation of public space. When they did so - as in the police action against young street dancers in Mahdia in March 2013, or the arrest of nineteen members of Fanni Raghman Anni at Le Kef in July 2013 during their performance of 'Guetlouh' ['they killed him' - referring to the murder of Chokri Belaid] - the police claimed that they were doing so to restore order since the performances had been violently attacked by salafis. This failed to convince the group and some held to the belief that because Ennahda dominated the government, the police were now in league with the salafis to prevent young people from reclaiming public space. ${ }^{22}$

The reactions of the security forces were far less ambiguous when it came to rap as an art form, in large part because the police were one of the main targets of the rappers' invective. A number of Tunisian rappers challenged the corruption, violence and abuses of the police, and were speaking for many of their class and generation who had found that despite the flight of the dictator and the changes at the summit of Tunisian politics, their continuing experience of the violence and contempt of the police suggested that little had changed. ${ }^{23}$ Unsurprisingly, given their stance, they found themselves prosecuted and jailed at regular intervals.

20 Bechir Abdelmoumen 'Kef: sauvés des griffes des salafistes, 19 artistes comparaissent devant le procureur', Webdo 7 July 2013 - http:/ / www.webdo.tn/2013/07/07/les-fannianni-se-reproduisent-a-gettar-tebourba-gafsa-et-se-font-arreter-au-kef/

21 Tunisialive Daily Archives 15 January 2015, Tunisialive - www.tunisialive.net/2015/01/15

22 Selim Ben Cheikh 'Quelle place et quell role pour l'art contemporain en Tunisie', Archivio Anthropologico Mediterraneo XVI (2013) 15/1 p. 90; Abdelmoumen (2013)

23 The analogous situation of the youth of poorer quarters of Cairo is well captured in Salwa Ismail 'The Egyptian revolution against the police', Social Research 79/2 (2012) pp. 435-462 
This occurred under successive post-revolutionary governments, regardless of their political colour. For some it underlined governments' continuing preoccupation with order and the array of potentially repressive 'public order' legislation that remained on the statute book; for others it was testimony to the unreconstructed nature of the police and the ministry of the interior in postrevolutionary Tunisia. In March 2013 the rapper Weld El 15 (Alaa Yaacoub) was sentenced to two years in prison in absentia (he had gone into hiding) for releasing a video on the internet of his song 'Boulissia Kleb' ['The Police are Dogs']. Whether because of the title, or because the lyrics called for the police 'to be slaughtered instead of sheep', he was indicted for threatening the police. When he turned himself in he was given a re-trial in June 2013, but was again sentenced to two years in prison. As Yaacoub said at the time 'In the song, I used the same terms that the police use to speak about the youth. The police have to respect citizens if they want to be respected' ${ }^{24}$

In fact, an appeal court reduced his sentence to six months and set him free after a month. Nevertheless, he vowed to continue with his work and his music. He did so to such good effect that in September 2013 he and fellow rapper Klay BBJ were indicted for singing the same song at a concert in Hammamet. He was convicted in December to four months in prison for 'an affront to public decency and insulting behaviour towards public servants'. He counter charged that even though he had not sung 'The Police are Dogs' at the concert, the police had attacked him and then beaten him up. He appealed against the sentence and won, being acquitted and released from jail two weeks after sentencing. ${ }^{25}$

Nevertheless, rancour within the police remained. Throughout 2014 Yaacoub alleged that the police had put pressure on a number of venues, forcing them to cancel his appearances. When he did appear in the summer of 2014 in Carthage a plain-clothes (but rather obvious) policeman recorded the whole performance to ensure that no allusion was made to the notorious song. As Yaacoub said, in some respects the song was no longer important, 'What matters to them [the police] is to forbid me from existing in my own country'. Nevertheless, the arrest of a young actor, Dhafer Ghrissa, in September 2014 on the charge of using a five second clip from Weld El 15's video in his one man show at Menzel Bourguiba, testified to the continued anger and sensitivity of the security services. Ghrissa's description of the violent and sudden intervention of the police who dragged him off for four hours of interrogation proved for him that 'they judged the broadcasting of 'Boulissia Kleb' as intolerable, which for them touches the honour and prestige of the State'. Ironically, their very behaviour tended to confirm their

24 Sihem Hassaini ‘Tunisian rapper Weld El 15 jailed for threatening police' BBC Africa News 13 June 2013 - http://www.bbc.co.uk/news/world-africa-22896036; for the song 'Boulissia Kleb' (some of it filmed in front of the notorious ministry of the interior in Tunis), see https://www.youtube.com/watch?v=6owW_Jv5ng4

25 Al-Akhbar 'Tunisian rapper Weld El 15 acquitted' Al-Akhbar English 19 December 2013 - http:/ /english.al-akhbar.com/node/17964 
description in the song itself as 'gangs in uniform' and in the words of Oussama Helal (Ghrissa's defence lawyer): 'the new Constitution guarantees freedom of expression and freedom of artistic creation. If the police intervene directly to censor a work of art, how can we guarantee freedom of expression in education, in the media and in public space? ${ }^{26}$

The feeling that this was indeed under threat was heightened among some Tunisian rappers and comedians as the country geared itself for new elections in late 2014, especially with the emergence of Nidaa Tounes as the leading party. Added to the enduring concerns about the unreconstructed security sector and its repressive instincts, were the fears that the large numbers of former members of the RCD and other associates of Ben Ali within Nidaa Tounes would mean a return of the intolerance of dissent and of free expression that had characterised the old regime. In this environment the rapper El General (who had been arrested in December 2010 and whose song 'Rais Lebled' had become virtually the anthem of the revolution) made a video clip spelling out the danger: ' $O$ RCD-ists...we thought we'd got rid of you but you've had the nerve to return'. Weld El 15 had himself been fiercely critical of Ennahda when it was in power, but in 2014 feared that a Nidaa Tounes victory would 'leave the door wide open to Ben Ali cronies, experts in the arts of censorship and repression'. And the comedian Lutfi Abdallah was disconcerted to find that having been praised for mocking Ennahda for three years, he was now accused by certain sectors of the press of having 'no humour, no respect' when he satirised Nidaa Tounes. ${ }^{27}$

For some, these fears were borne out in 2015 when two cultural spaces in Tunis Mass' Art and the Whatever Saloon (Café El Louh) - were closed down in quick succession in the spring of 2015. Mass' Art in Bab Lassal had been founded to provide a venue for multidisciplinary artists and the youth of this poor quarter of Tunis to interact. Its director, Salah Hammouda, and the artists, journalists and local youths who staged a protest demonstration in front of the premises when it was ordered to close in March saw this as the latest in a series of moves by the authorities that had always been uneasy about the venue's counter-culture nature. This impression was reinforced when the minister of culture, Latifa Lakhdar, claimed that she was powerless to intervene to save it from closure. As with the Whatever Saloon, which was closed abruptly in May by the ministry of the interior on grounds of questionable legality, it had been a venue where rappers and alternative cultural expression could perform. Just before its forced closure Whatever Saloon had hosted the festival of improvised song and music, El Chanti, the Tunisian version of the international 'La Voix est Libre' movement

26 Henda Chennaoui '"Boulissia Kleb" n'en finit pas de faire enrager les policiers: les poursuites contre l'artiste Dhafer Ghrissa', Nawaat - rights, 23 September 2014 http:/ / nawaat.org/ portail/2014/09/23/ boulissia-kleb-nen-finit-pas-de-faire-enragerles-policiers-des-poursuites-contre-lartiste-dhafer-ghrissa/

27 News24 'Tunisia artists, media fear for freedoms after election', News24, 19 November 2014 - www.news24.com/Africa/News 
that had become so popular across the Middle East and North Africa. And it was planning a rap concert that would have featured rappers like Klay BBJ. For its manager and owner, Wael Mhamdi, the suspicion with which the ministry of the interior had looked upon this and other activities was the cause of the closure order. As he said at the time, it was important to remember the problems that the police still have with Tunisian rap and particularly with Klay BBJ 'their promises to block all his concerts in Tunisia still echo in our ears. ${ }^{28}$

\section{Engaging with the public: recognition and difference}

The struggle to maintain public space as a space for free expression, for the recognition of rights and for the enactment of the liberties, as well as the responsibilities of the citizen is not simply a fight against the encroachment of the forces of the state, whether in the police or those holding public office. It is also a struggle to determine what and who can act in public space, the rules of toleration and thus the striving for mutual recognition of different and sometimes opposing perspectives within a plural public. ${ }^{29}$ It is this that makes it truly a space where a public constituted of free citizens can find expression, where they have freedom to differ, but where they can also recognise themselves in others. It is the public realm in the sense used by Hannah Arendt, 'that relates and separates men at the same time'. ${ }^{30}$ As such it is also a space of contention. Ideally this will be regulated by general acceptance of the rules for the toleration of difference, but there is always a possibility that antagonism can develop into open conflict and may then be used by state authorities to intervene on the pretext of restoring order. This was the case at Le Kef when the performance of 'Guetlouh' by Fanni Raghman Anni was attacked by salafis incensed by the suggestion that they were implicated in the murder of Chokri Belaid, or possibly outraged by the mode of selfpresentation and undress of the performers. ${ }^{31}$

Citizen-artists in Tunisia have been highly visible in such struggles not only because they are concerned about issues of censorship, restrictions on expression and the exclusion of their art from public space, but also because it is in the nature of their art to be placed in the public gaze. It is meant to inform, to mobilise and to

28 Henda Chennaoui 'Décision de fermeture d'un autre espace culturel à Tunis', Nawaat - culture 26 May 2015 - http:/ / nawaat.org/portail/2015/05/26/decision-de-fermetureespace-culturel-tunis-whatever-saloon/; Henda Chennaoui 'Mass' Art: un espace culturel alternative menacé de fermeture', Nawaat - culture 10 March 2015 -

http:/ / nawaat.org/portail/2015/03/10/ massart-un-espace-culturel-alternatif-menacede-fermeture/

29 The case of the rapper Hamadi Dia, threatened in his home town of El Reqab in 2014 by Islamists for criticizing them, shows that social intolerance can be as potent and as menacing as that of the security forces, Shaima Aly 'Tunisia: no investigation into attack on rapper', Freemuse 6 July 2015 http:/ / freemuse.org/archives/10427

30 Hannah Arendt The Human Condition (Chicago: University of Chicago Press, 1998) pp. 198-9

31 Abdelmoumen (2013) 
engage the public, to communicate values and to make normative statements about social and political practices. Many also see it as their duty to provoke, to push the boundaries of public taste, to shake up the conventions governing what can and cannot be seen in public. Others may have very specific ideological agendas that they feel need to assert at every opportunity. ${ }^{32}$ Inevitably they will meet opposition and in some respects this is intended. Not everyone will like what they see, and one person's 'making visible' may strike a discordant note because its subject matter or mode of depiction outrages the spectators' feelings. ${ }^{33}$ The conventions of visibility are always in some sense selective and artefacts may be presented in such a way that they privilege only a few cognoscenti. This is part of the inbuilt instability in artistic creation and underlines the difficulty of 'putting art to work' in any very obvious or instrumental way.

Encountering and communicating with a plural public has been a challenge for contemporary artists in Tunisia, especially since many of them are committed to keeping open spaces where those who disagree with them and dislike what they do are as entitled to a presence as they are themselves. The resulting tensions have been highly visible in the visual arts as well as in the spheres of dance and public performance. However, there have been moments of mutual comprehension and solidarities have emerged that have succeeded in expanding public space. This has often been due to a determination by groups such as 'Art Rue/Cheraa Fann', 'Art Solution' and 'Klem Cheraa' ${ }^{34}$ to address directly the regional and socio-economic divides that mark Tunisian society and that may reinforce mutual incomprehension and prejudice.

It was in this spirit that Sélim Tlili in his 'Art for Tunisia' project in late January 2011 invited passers-by to join him in painting a huge portrait of Mohamed Bouazizi on Avenue Bourguiba in Tunis; or that Faten Romissi in February 2011 in her project 'Art dans la rue - Art dans le quartier' worked with inhabitants of a run-down quarter of Tunis and art students to decorate burned out cars abandoned during the revolution; or that Bahri Ben Yahmed of the association 'Art Solution' initiated public dance performances in the project 'Je danserai malgré tout' that encouraged public participation in squares, markets and streets

32 This was also part of the motivation behind the Femen inspired topless protests of Amina Sboui (Tyler) and others in Tunis in 2013 - Eline Gordts 'Amina Tyler, topless Tunisian FEMEN activist, sparks massive controversy', The World Post, 26 March 2013 http://www.huffingtonpost.com/2013/03/25/amina-tyler-femen_n_2949376.html 33 For participants in the Artocratie event in 2011, it was disconcerting to find that in some places the huge portraits that they had plastered up in public spaces as a reclamation of public space were then torn down by citizens for a variety of reasons, including not wishing to have huge portraits of anyone imposed on them anymore, and not considering the 'ordinary' nature of the people portrayed to justify the prominence of their portraits - interview with Héla Ammar, 2 April 2013, Sidi Bousaid

34 Interview with Majd Mastoura, 14 April 2014, Tunis 
not only of Tunis but of towns up and down the country. ${ }^{35}$ Selim Ben Cheikh, a visual artist stung by a politician's accusation that contemporary artists in Tunisia were only working in a bourgeois bubble, detached from 'la Tunisie profonde' that had rejected them, took his art to the remote countryside. Working together with the villagers of Chnénni, a Berber village in southeast Tunisia, he and they created a stunning piece of 'land art' on the escarpment opposite the village. As he explained at the time, the project was a double challenge: firstly, to show his work beyond the confines of the capital and its suburbs, taking contemporary art to the most deprived regions of the country; secondly, to assert the presence of contemporary art in the natural landscape, 'rather as the salafists do when they occupy a hill to create their prayer spectacle' ${ }^{36}$

Ben Cheikh's reaction to the disparaging remarks made by a minister about contemporary art referred to the June 2012 events surrounding the exhibition of contemporary art, the 'Printemps des Arts' exhibition at the Abdellia Palace in La Marsa where Ben Cheikh had shown his work. It became something of a cause célèbre in which people adopted directly opposing positions that for them epitomised the larger political struggle in Tunisia at that time, as well as drawing attention to the role of artists in the wider political context. Meriem Bouderbala, the exhibition's curator, wrote: 'in the current context, it is all about occupying cultural territory, of allowing everyone access to it and contributing to a strong democratic cultural constitution that demonstrates the strength of Tunisia's creative potential. ${ }^{37}$ The reaction may not have been as she anticipated, although the curatorial decision to place Faten Gaddes's large and striking work 'Le Ring' (a boxing ring in which hung three punchbags bearing a photograph of a woman's face, her hair made to look like a hijab, labelled 'Je suis chrétienne', 'Je suis juive', 'Je suis tunisienne') was not fortuitous. Indeed, a number of the works were clearly intended to show their creators' fears at the time about the future of artistic freedom and the status of women under a government coalition dominated by the Islamist Ennahda party, the largest party in the National Constituent Assembly. Some expressed these concerns in works that made manifest their views about the social, educational and coercive practices that they associated with restrictive interpretations of Islam. Nadia Jelassi created a disturbing installation of three women in chadors, buried to the waist, clearly prepared for stoning to death as practiced in the Islamic Republic of Iran and in Afghanistan under Taliban rule. Mohamed Ben Slama painted a large picture of a naked woman, wearing rubber washing up gloves, with a dish of couscous hiding her genitals, and surrounded by bearded men. He also created an installation

35 Machghoul (2013); Selima Karoui ‘Réaménagement du secteur de l’art dans les régions intérieurs par l'investissement de la société civile (II)', Nawaat - culture 11 January 2014 http://nawaat.org/portail/2014/01/11/ reamenagement-du-secteur-de-lart-dans-lesregions-interieures-par-linvestissement-de-la-societe-civile-ii/

36 Ben Cheikh (2013)

37 Anthony Downey 'For the Common Good - artistic practices, collective action and civil society in Tunisia', Ibraaz February 2013 pp. 5-6 - www.ibraaz.org/essays/55 
where ants were crawling out of a child's school satchel, spelling out the words 'Subhana llah' [God be Praised!] across the wall. ${ }^{38}$

Ironically, it was on the day that the exhibition closed that the trouble began. A former employee of the courts, but also a member of a party associated with the disbanded RCD, took photos of some of the works and showed them to members of the congregation at the nearby mosque of La Marsa. This caused a small crowd to march on the Abdellia Palace, demanding that the works be taken down immediately since they were 'attacks on the Muslim religion'. Supporters of the exhibition gathered and confronted the protestors. The director of the exhibition, Luca Lucattini, rather optimistically stated that 'For once, there was a real exchange of ideas, not simply invective carried out at a distance on Facebook' ${ }^{39}$ In the end the protestors dispersed, made aware by the police that the exhibition was legal and that it would be closing that evening anyway.

It was during that night that violence broke out. Youths broke into the Abdellia Palace, attacked the offending works and dragged Gaddes's 'Le Ring' out into a nearby crossroads and burned it. This coincided with more serious rioting in some of the poorer quarters of Tunis and in some of the more deprived provincial towns, where police stations and court buildings were attacked. Because social media publicised these events, as well as calls for the punishment, even death of the artists concerned and for the need to rally in 'defence of Islam', many, including some government officials, attributed the violence to the righteous anger of those whose religious sensibilities had been outraged by the art works at 'Le Printemps des Arts'. In fact, the systematic nature of the riots, their synchronised eruption, as well as the nature of their targets suggested that something else was going on. Courts had just acquitted three members of the security forces accused of killing protesters in Thala and Kassrine in December 2010 - January 2011, provoking fury at what was regarded as a state cover up. Equally, it may have been significant that just before the incidents at La Marsa, Ayman al-Zawahiri, the leader of Al-Qaida, had called on all 'defenders of the shari ' $a$ ' in Tunisia to rise up and overthrow the Ennahda led government. And some saw in the simultaneous riots the hand of agents provocateurs of the old regime, seeking to destabilise their revolutionary successors, by exploiting a number of social fracture lines. ${ }^{40}$

38 Rachida Triki 'Freedom to express: the Abdellia Affair', Ibraaz 23 August 2012 www.ibraaz.org/news/30

39 Priscille Lafitte 'Une exposition d'art contemporain à l'origine des heurts à Tunis?', France 24 - culture 14 June 2012 - http:/ / www.france24.com/ fr/20120612-tunisie-heurtstunis-exposition-art-contemporain-printemps-marsa-salafistes

40 Lafitte (2012); interview with Héla Ammar, 2 April 2013, Sidi Bousaid;

Kerim Bouzouita 'Tunisia's ground zero for creative freedom', October 2012 All that is banned is desired Freemuse 2012 - http:/ / artsfreedom.org/wpcontent/uploads/2012/10/Article02_AbdelleyaAffair.pdf 
Understandably unnerved by the death threats made against some of their number, compounded by Shaikh Houcine Laabidi of Zeitouna mosque calling for their blood as well, many in the artistic community were also perturbed by the immediate response of the government. It seemed to be ominous for the future of artistic freedom and thus for the freedom of public space in Tunisia that the minister of the interior as well as the minister of culture, Mehdi Mabrouk, hastened to condemn the artists. This was on the basis of often inaccurate representations of the works circulating on social media - works that they had not themselves even seen. Mabrouk in particular was roundly condemned by Nadia Jelassi, who said that 'By condemning the artists, he abandoned his true role and function: promoting and protecting art and artists. He was now seen as a minister who censures, an enemy of culture' and she mocked him for his performance at a press conference when he had 'railed against "mediocre self-taught people who have nothing to do with art", blaming them for the crisis, since "art shouldn't be revolutionary, it must be beautiful"'. ${ }^{41}$

It was in this feverish atmosphere, when the artists felt that they were being made scapegoats to deflect attention from the failings of government itself that Ennahda tried to mobilise support for the insertion of a clause into the constitution to proscribe any 'attack on religion' such as this art exhibition was alleged to have been. The vindictive nature of the government's pursuit of the artists became clear a few days later. Nadia Jelassi and Mohamed Ben Slama were informed that the state prosecutor had opened a case against them and in August they were charged at the Tunis Court of First Instance with 'breach of the peace and moral standards' under Article 121.3 of the Penal Code. Notoriously and ominously for the future of freedom of expression this was the law introduced by Ben Ali in 2001 and used countless times by his regime to prosecute human rights activists and political dissidents. When Jelassi appeared in court, the judge asked her outright what her intentions were and whether she wanted to provoke people through her work, as if this were in itself a crime.

In fact, Jelassi turned her experiences at the hands of the police into a visual indictment of the system, photographing herself holding up a ruler to her face in mockery of the photometric session that the police had forced her to undergo. This went viral on social media and encouraged countless people to express solidarity by doing likewise. As the visual artist Rachida Amara explained, this was intended to show 'Rule by show of hands against imposed rules'. It was in fact the turning point in the case. The campaign in support of the artists gathered strength in Tunisia and internationally, bringing about a spectacular reversal in the position of the minister of culture in September 2012. He declared that he 'fully supported the artists' and a day later a spokesman for the President of the Republic said that 'the Presidency is against proceedings being taken against artists and we are against legal proceedings where freedom of expression is

41 Bouzouita (2012) 
concerned' ${ }^{42}$ The charges against the artists were dropped. But it left an uneasy feeling amongst many, not simply about the depth of public opposition to unfamiliar and perhaps shocking forms of artistic expression, but also about what happens when the polarisation of national politics becomes entwined with cultural and artistic differences. It is then, as the initial moves by the authorities demonstrated in this case, that public space, as a space of rights to freedom of expression, is truly threatened.

Other artists in other media had also been challenged by members of the public objecting to their interventions for a variety of reasons. However, this challenge is in many senses constitutive of public space itself, pushing the boundaries and clarifying what can and what cannot be shown in such spaces. For the 'calligrafitist' El Seed, whose spectacular Arabic calligraphic murals have given him international renown, the goal after the revolution 'is how we can stick together'. In this spirit, in 2012 he decorated one side of the enormous minaret of the Jara mosque in his home town of Gabès with his 'calligraffiti' of the Quranic verse concerning difference and tolerance: 'Oh humankind, we have created you from male and female and made people and tribes so that you may know each other' [Qur'an, 49 Surat al-hujurat, v. 13] He described this work as 'not about decorating a mosque - it is about making art a visible actor in the process of cultural and political change' ${ }^{43}$ For him, arguments about the place of religion were merely distractions 'they are setting people against one another, to hide the real problems of unemployment, of the economy'. In such a situation art was the solution - 'You open a dialogue and ask real questions. True art can really awaken people and give them the feeling that they can do something with their minds and their hands' ${ }^{44}$

Given the style, the content and the site of El Seed's work, it was not surprising that he did not face opposition from those with a more conservative or salafi outlook. Nevertheless, even where that has been the case it has often spurred artists to engage with their critics, seeking to broaden their appeal to a wider public but also asserting their right to make their art in public space. Thus, Bahri Ben Yahmed, initially part of the collective 'Art Solution' and then founder and leader of the association 'Danseurs Citoyens', admitted that he and his colleagues had been spurred on by the hostile salafi reaction in March 2011 when the citizen dancers had performed in public space. Salafis had jostled and abused the dancers, shouting at them 'Go back into your theatres; the street doesn't belong to you.' It made him and his colleagues all the more determined to assert their right to practice their art in public space, 'even if the radical Islamist current tries to chase artists out of public space in order to use it as a space to spread ideological propaganda and thus to Islamise all our common spaces'. The group released a

42 Bouzouita (2012)

43 El Seed http://elseed-art.com/minaret-of-jara-mosquee/

44 Shabi (2013) 
video 'Je danserai malgré tout' but then developed the theme into much more than an act of defiance against salafis. Rather, it was intended to mean 'in spite of all forms of censorship - religious, political, social - in spite of anyone at all who wants to gag, or try to gag the free expression of the body in our society'. ${ }^{45}$

For this reason the group sought engagement with ordinary citizens and although they met initially with indifference, they also found that when they added music to the performances people of all kinds were drawn in to dance in the streets and squares. This gave birth to the project 'Resisdance' where the Danseurs Citoyens travelled around Tunisia in a bus stopping at obscure villages in the provinces and were gratified by what they discovered: 'We found people listening, concentrating and appreciating in a quite exceptional way. It was then that we realised the creative and participatory potential of Tunisians, completely against the image often found in the media which seeks to turn one against the other, fearing each other and the unknown'. Bahri Ben Yahmed was committed to develop this participatory art form and to do so not simply through spectacles and interventions. He took it further by initiating regular training and dance classes for young people from the disadvantaged suburbs of Tunis and of the provinces, something that the state authorities had singularly failed to do. ${ }^{46}$

The realisation that public space was above all a space of meaningful participation in which citizens would have a stake, had two particular implications for Tunisian artists concerned with its defence and with the defence of the rights of citizens more generally. The first required them to communicate with and to involve citizens across the country, not simply in the capital. As with the activities of the Danseurs Citoyens there was a need to train, persuade and encourage participation. The second was to ensure that as wide a spectrum as possible of citizens should have access to public space, that they should not be excluded for reasons of gender, race, belief or poverty. ${ }^{47}$ This had been part of the thinking of the organisation Art Rue/Cheraa Fann since its inception in 2006. Legally recognised only after the revolution in 2011, Art Rue had nevertheless been responsible for the Dream City events that had taken place every two years, beginning in 2007, focusing on the public spaces of the old medina of Tunis and also, in 2012, of Sfax. Selma and Sofiane Ouissi, both dancers and choreographers, had brought together talented and like-minded Tunisian artists visual artists, photographers, performance artists - and some international artists to show their art in the public spaces of the medina even under the wary eye of Ben Ali's regime. They managed to stage the series of events that constituted

45 Selima Karoui ‘Danseurs Citoyens - entretien avec Bahri Ben Yahmed: la résistance, par la danse, comme une lute contre tout forme d'obscurantisme', Nawaat - culture 31 March 2014 - http:/ / nawaat.org/portail/2014/03/31/danseurs-citoyens-entretien-avecbahri-ben-yahmed-la-resistance-par-la-danse-comme-une-lutte-contre-toute-formedobscurantisme/

46 Karoui (2014); Dahmani (2013)

47 Interview with Badr Baabou, 7 April 2014, Tunis 
Dream City and, in doing so, had affirmed the 'power of creativity, of détournement, of citizenship and of the collectivity as a form of resistance and an act against oppression' ${ }^{48}$

After the revolution Art Rue organised Dream City 2012 with the theme 'L'Artiste face aux libertés', seeking to find alternatives to existing systems of domination by 'initiating a revolution of ways of thinking where the street is our site of liberty and of exchanges: it is for the users to construct their narratives and to act them out collectively'. ${ }^{49}$ The multiple artistic interventions during the weeks that it lasted were intended to celebrate the freedoms made possible by the revolution, but also to construct situations in the public spaces of the medina that would create encounters and exchanges, engaging people aesthetically, making participation enjoyable and affecting, but also encouraging people to think about what it means to live together responsibly and how art can help them do so. ${ }^{50}$ It was very much part of the intention of the project to question the social and political role of the artist, seeing art as a force of intervention in society. It explored the ways in which the metaphorical language of art can involve citizens in the understanding and creation of democratic possibility, but it also, as in the work 'Tisser la Médina' by Sonia Kallel, one of the participating artists, brought to light some of the restrictions that dominant economic forces were imposing on their environment and on their society. ${ }^{51}$

This was supplemented by other artistic initiatives of a practical nature such as the Laaroussa project of 2011 that brought together some sixty women potters from the Sejnane region in northwest Tunisia with artists from other parts of the country so that each group could learn from the others. The work of the Sejnane potters is distinctive and highly accomplished - and sought after. The intention was to help the women to set up a cooperative that would allow them not only to develop their own skills, but also to avoid the financial exploitation to which many of them were subject by dealers who sold on these women's work for sums that the women themselves could scarcely imagine. ${ }^{52}$ In addition, Art Rue organised and ran a three week workshop in the medina of Tunis in November 2014, aimed at training young artists from across Tunisia in conjunction with international students from the FAI-AR (Formation supérieure d'art en espace publique) in Marseille. The workshop deployed multiple forms of artistic interventions - visual art, theatre, dance, movement and music/sound - in the

48 Dream City collective 'Dream City - actions artistiques dans l'espace urbain' Z.A.T. [Zone Artistique Temporaire] - penser la ville artistiquement, No 2, May 2011, p. 60

49 'Dream City', Z.A.T. (May 2011)

50 Triki (2013) p. 26;

51 Association l'Art Rue Dream City 2012 - l'artiste face aux libertés (Tunis, 2012) p. 40; Interview with Sofiane Ouissi and Dhouha Bokri, 18 April 2014, Tunis

52 Dream City collective Z.A.T. - penser la ville artisiquement No 3 August 2011; Interview with Béatrice Dunoyer, 8 September 2014, La Marsa 
public spaces of the medina, on the unifying theme of 'Conflicts and resistances: the citizen artist and Tunisian public space'. ${ }^{53}$ Like many other artists and activists, Art Rue was taking the idea of the artist-citizen seriously and was trying to engage citizens in public space not simply through spectacle and diversion, but also through participation and training.

\section{Conclusions}

All systems of power are based on principles of exclusion and inclusion regarding individuals, ethical norms and forms of behaviour. These can be imposed on a community, or on sections of a community, or they can be debated, recognized and agreed. Therefore the terms of these principles and their implications for political action, for sociability, for citizens' rights and for their life chances must be at the basis of any democratic discussion. It is in this regard that public space plays such a vital role in sustaining but also stimulating the public exchanges that help a community discover its common interests, but also its fault lines.

Consequently, public space in its widest sense demands constant efforts to provide a 'space of appearance' through constant challenge and counterchallenge, questioning who sets the rules and whether they are they openly contestable.

Art has the exceptional capacity to provoke debate about these principles, often in oblique but nevertheless powerfully affecting ways. As the years following the overthrow of Tunisia's dictator bear witness, this has been a marked feature of political debate and contestation in the country. It has led to an explosion of creative activity, as well to serious debate and argument about the role and the form that artistic interventions might assume. Many of these have challenged state power and the power of social and religious convention, often provoking painful self-examination and dissection of the prejudices of artist and spectator alike. This has caused sometimes violent reactions against medium and message, as well as against certain artists, allowing the 'entrepreneurs of prejudice' to make political capital from the condemnation, but also from the co-optation of creative artists.

But equally, art has the power to create or to assist in the creation of social memory, developing through common affect a collective sense of our potential as citizens and bonds linking us to others. Such a form of mutual recognition is also a key part of the constitution of public space, since it helps to create the basis on which the public sees itself as a bearer of citizens' rights, as well as the duties of citizens towards each other. This been much in evidence in Tunisia. It can be seen in Zoo Project's full size depictions throughout public space in Tunis of those who were killed in the revolution ${ }^{54}$, or in Patricia Triki's 'Checkpoints' installations ${ }^{55}$,

53 Association l'Art Rue http://www.lartrue.com/fr/Formation_artistique.php

54 Zoo Project gallery - http://www.theguardian.com/globaldevelopment/gallery/2011/may/20/tunisia-murals-zoo-project-in-pictures 
or in the performances of groups like Danseurs Citoyens and Art Rue. All have consciously sought to engage, as well as to encourage the public to think of the potential of activist citizenship, in addition to alerting them to the dangers that can threaten individual autonomy and collective solidarity.

An artistic intervention is in many senses intended to provoke strong emotions in its methods of presentation, in the techniques it deploys and also in the repertoire on which it draws. Tunisian artists have discovered that this has raised troubling questions about whether they are only ever speaking to the like-minded, to a narrow and perhaps privileged circle of those familiar with particular forms of artistic expression. As in other countries, bewildered, often hostile reactions to their work have been interpreted by some as proof of an irredeemable philistinism in sectors of the population or of the state machinery. On occasion these feed off each other, suggesting an unbridgeable distance between much of the public and the artists, with a correspondingly competitive attitude to the occupation of public space (a sentiment reciprocated by many of those who have reacted negatively to their works). ${ }^{56}$ Such concerns echo the polarisations of national and party politics in Tunisia, with the fear that public space will be seen less as a site for the exercise of the rights of the public, and more as a space to be conquered and dominated by one force, to the exclusion of others.

Tunisians scarcely need reminding that they have been here before. Indeed, it could be said that the Tunisian revolution was a reaction to the pernicious consequences of such ambitions. This has raised the question for some Tunisian artists of whether they have an obligation, as citizens, to enter into a dialogue with those whose hostility to their forms of art seemed initially to be a barrier to its message and to its power. ${ }^{57}$ If art is intended to get inside the head, to reach the heart, to affect the subject then clearly artists need to address how people encounter and perceive their art. This has encouraged a number of Tunisian artists to engage the public precisely to understand how others see, as well as to help to train them in seeing. For some, it is a process of mutually constitutive, sometimes tentative recognition and comprehension, far from the sequestered spaces of commercial galleries, or from the didactic clamour of the partisan billboard that are both features of the Tunisian urban environment.

Such a process itself enacts public space, giving it both form and substance. In doing so, it revives the idea of moral emotion as a form of ethical knowledge through affect, communicated through art that does not simply move the subject,

55 Pat art-qui-degage_791143?photo_id=376499

56 Lea Ypi 'Public spaces and the end of art', Philosophy and Social Criticism 38/8 (2012) pp. 850-6

57 The encounters and eventual dialogue between members of the graffitist group Zwewla and their salafi opponents during 2013-14 are significant in this respect. Interview with Badr Baabou, 7 April 2014, Tunis 
but also creates new kinds of knowledge. In its centrality to the making of public space, art can therefore play a role similar to that of normative political theory. As multiple examples in Tunisia have shown, it can alert people to key features of the fields of power that govern their lives. Artistic interventions interpellate members of the public, urging them to make ethical and political judgments about what they are seeing in art and through art. In the field of Tunisian politics, this was not simply visible in the revolt against the dictatorship of Ben Ali. Such interventions remain a feature of the Tunisian political landscape, expressing in their modes of expression and in their content a diversity of views about Tunisian society. In doing so, they are not merely commenting on, but are integral to the processes of public discussion and indeed disagreement that will help to define the democratic potential of Tunisia's Second Republic.

\section{Bibliography}

Bechir Abdelmoumen 'Kef: sauvés des griffes des salafistes, 19 artistes comparaissent devant le procureur', Webdo 7 July 2013 -

http:/ / www.webdo.tn/2013/07/07/les-fanni-anni-se-reproduisent-a-gettartebourba-gafsa-et-se-font-arreter-au-kef/

Al-Akhbar (2013) 'Tunisian rapper Weld El 15 acquitted' Al-Akhbar English 19 December 2013 - http:/ / english.al-akhbar.com/node/17964

Héla Ammar Corridors (Tunis: Cérès Éditions, 2015)

Hannah Arendt The Human Condition (Chicago: University of Chicago Press, 1998)

Association l'Art Rue Dream City 2012 - l'artiste face aux libertés (Tunis, 2012)

Association l'Art Rue http:/ / www.lartrue.com/fr/Formation_artistique.php

Abdelaziz Belkhodja \& Tarak Cheikhrouhou 14 janvier - l'Enquête (Tunis: Apollonia editions, 2013)

Selim Ben Cheikh 'Quelle place et quell role pour l'art contemporain en Tunisie', Archivio Anthropologico Mediterraneo XVI (2013) 15/1, pp. 89-96

Kerim Bouzouita 'Tunisia's ground zero for creative freedom', October 2012 All that is banned is desired Freemuse 2012 - http://artsfreedom.org/wpcontent/uploads/2012/10/Article02_AbdelleyaAffair.pdf 
CDH 'Notes on the commodification of street art', Art Monthly Australia 263 (September 2013) pp. 42-44

Henda Chennaoui "'Boulissia Kleb" n'en finit pas de faire enrager les policiers: les poursuites contre l'artiste Dhafer Ghrissa', Nawaat - rights, 23 September 2014 http:/ / nawaat.org/ portail/2014/09/23/ boulissia-kleb-nen-finit-pas-de-faireenrager-les-policiers-des-poursuites-contre-lartiste-dhafer-ghrissa/

Henda Chennaoui 'Mass' Art: un espace culturel alternative menacé de fermeture', Nawaat - culture 10 March 2015 -

http:/ / nawaat.org/portail/2015/03/10/massart-un-espace-culturel-alternatifmenace-de-fermeture/

Henda Chennaoui 'Décision de fermeture d'un autre espace culturel à Tunis', Nawaat - culture 26 May 2015 - http:/ / nawaat.org/portail/2015/05/26/decisionde-fermeture-espace-culturel-tunis-whatever-saloon/

Laryssa Chomiak 'Spectacles of power: locating resistance in Ben Ali's Tunisia', Portal 9 Issue No. 2 The Square, Spring 2013 p. 1 - http://portal9journal.org

Frida Dahmani 'Tunisie: la danse, art du combat', Jeune Afrique 27 February 2013 - www.jeuneafrique.com/138214/culture/

Luke Dickens 'Pictures on Walls? Producing, pricing and collecting the street art screen print', City 14/1-2 (2010) pp. 63-81

Anthony Downey 'For the Common Good - artistic practices, collective action and civil society in Tunisia', Ibraaz February 2013 pp. 1-18 $\underline{\text { www.ibraaz.org/essays/55 }}$

Dream City collective 'Dream City - actions artistiques dans l'espace urbain' Z.A.T. [Zone Artistique Temporaire] - penser la ville artistiquement, No 2, May 2011

Dream City collective Z.A.T. - penser la ville artistiquement, No 3, August 2011

Kaveh Ehsani 'Radical Democratic Politics and Public Space', International Journal of Middle Eastern Studies 46 (2014) pp. 159-162

El Seed http:/ / elseed-art.com/minaret-of-jara-mosquee/

Dario Gamboni, The Destruction of Art - iconoclasm and vandalism since the French Revolution (London: Reaktion Books, 1997)

Dounia Georgeon film: 'Murs blancs, peuple muet' (2011) -

http:/ / latelelibre.fr/libre-posts/doc-murs-blancs-peuple-muet/ 
Dounia Georgeon 'Revolutionary graffiti: street art and revolution in Tunisia', Wasafiri 27/4 (December 2012) pp. 70-75

Khadija Hamdi 'On the path of contemporary Tunisian art', Contemporary Practices - visual arts from the Middle East Volume IX (2013) http:// www.contemporarypractices.net/essaysv9.html

Sihem Hassaini ‘Tunisian rapper Weld El 15 jailed for threatening police' BBC Africa News 13 June 2013 - http:/ / www.bbc.co.uk/news/world-africa-22896036

Insitut für Auslandsbeziehungen (IFA) Rosige Zukunft/Un Avenir en Rose - Aktuelle Kunst aus Tunesien/Art actuel en Tunisie (Berlin: Kerber Verlag, 2012)

Salwa Ismail 'The Egyptian revolution against the police', Social Research 79/2 (2012) pp. 435-462

JR Artocratie en Tunisie - projet Inside Out de JR (Tunis: Cérès editions, 2011)

Selima Karoui ‘Réaménagement du secteur de l'art dans les régions intérieurs par l'investissement de la société civile (II)', Nawaat - culture 11 January 2014 http:/ / nawaat.org/ portail/2014/01/11/reamenagement-du-secteur-de-lartdans-les-regions-interieures-par-linvestissement-de-la-societe-civile-ii/

Selima Karoui 'La place de l'art dans l'espace public tunisien' (I) Nawaat 3 March 2014 - https:/ / nawaat.org/portail/2014/03/03la-place-de-lart-dans-lespacepublic-tunisien-1/

Selima Karoui 'La place de l'art dans l'espace public tunisien' (II) Nawaat 18 March 2014 - http:/ / nawaat.org/ portail/ 2014/03/18/la-place-de-lart-danslespace-public-tunisien-2/

Selima Karoui ‘Danseurs Citoyens - entretien avec Bahri Ben Yahmed: la résistance, par la danse, comme une lute contre tout forme d'obscurantisme', Nawaat - culture 31 March 2014 -

http:/ / nawaat.org/ portail/2014/03/31/danseurs-citoyens-entretien-avec-bahriben-yahmed-la-resistance-par-la-danse-comme-une-lutte-contre-toute-formedobscurantisme/

Omar Kholeif 'The Social Impulse: politics, media and art after the Arab uprisings', Art and Education (2012) pp. 3-4 - www.artandeducation.net/paper/

Nicholas Korody 'The Revolutionary Art: Street Art Before and After the Tunisian Revolution' (2011) Independent Study Project (ISP) Collection, Paper 1134 http://digitalcollections.sit.edu/isp_collection/1134 
Priscille Lafitte 'Une exposition d'art contemporain à l'origine des heurts à Tunis?', France24 - culture 14 June 2012 - http:/ / www.france24.com/fr/20120612tunisie-heurts-tunis-exposition-art-contemporain-printemps-marsa-salafistes

Aurélie Machghoul 'Tunisie: l'art en espace public, révélateur des enjeux d'une société', Archivio Anthropologico Mediterraneo XVI (2013) 15/1, pp. 29-44

Coline Milliard 'From the ashes of Tunisia's revolution, a contemporary art scene grows: a Q \& A with curator Khadija Hamdi', Artinfo UK, 22 May 2012 http:// origin-www.artinfo.com/news/story/805447

News24 (2014) 'Tunisia artists, media fear for freedoms after election', News24, 19 November 2014 - www.news24.com/Africa/News

Jamal Penjweny 'Saddam Is Here' (2010) http://www.jamalpenjweny.com/Foto.aspx?jmara=5

Jacques Rancière The Politics of Aesthetics - the distribution of the sensible (London: Continuum, 2004) (tr. Gabriel Rockhill)

Amanda Rogers 'For a leaderless revolution, a monument with no curator: a walk through Imed Trabelsi's looted villa', Mideast Art 12 July 2012 -

http:// www.aslanmedia.com/arts-culture/mideast-art/7267-for-a-leaderlessrevolution-a-monument-with-no-curator-a-walk-through-imed-trabelsi-s-looted$\underline{\text { villa }}$

Rachel Shabi 'The Arab Spring began in Tunisia and now its artists and dancers are keeping the flame of protest alive', Aeon 9 May 2013 http://aeon.co/magazine/culture

Siobhán Shilton 'Art and the "Arab Spring": aesthetics of revolution in contemporary Tunisia', French Cultural Studies, 24/1 (2013) pp. 129-145

Neil Smith and Setha Low 'Introduction: the imperative of public space', in S. Low and N. Smith (eds.) The Politics of Public Space (London: Routledge, 2006)

Maria Antonietta Trasforini 'Contemporary art and the sense of place - the case of Tunisia', Archivio Anthropologico Mediterraneo XVI (2013) 15/1, pp. 13-23

Patricia Triki ‘Checkpoints' - http:/ / next.liberation.fr/arts/2012/01/25/entunisie-1-art-qui-degage_791143?photo_id=376499

Rachida Triki 'Freedom to express: the Abdellia Affair', Ibraaz 23 August 2012 www.ibraaz.org/news/30 
Rachida Triki 'Enjeux sociopolitiques des arts contemporains en Tunisie', Archivio Anthropologico Mediterraneo XVI (2013) 15/1, pp. 25-27

Tunisialive Daily Archives 15 January 2015, Tunisialive - www.tunisialive.net/2015/01/15

Weld El 15 (2013) https://www.youtube.com/watch?v=6owW_Jv5ng4

Lea Ypi 'Public spaces and the end of art', Philosophy and Social Criticism, 38/8 (2012) pp. 843-860

Zoo Project gallery - http:/ / www.theguardian.com/globaldevelopment/gallery/2011/may/20/tunisia-murals-zoo-project-in-pictures 